gouty diathesis, and had for years suffered from uric acid gravel in the urine. On November 7 th of the same year, the hearing distance for the watch was one inch with the right, and three inches with the left ear. The right meatus was swollen, and contained bright yellow discharge. The left was more swollen, but contained less discharge. Both tympanic membranes appeared red and swollen, so that the malleus could only be indistinctly made out on the right side--not at all on the left. After removal of the discharge, no perforation-sound was obtained in either ear on inflation. Treatment, consisting locally of frequent cleansing, the application of iodine to the mastoid processes, insertion into the auditory canals of Gruter's gelatine globules (containing sulphate of zinc and tannin), instillation of drops of bicarbonate of soda, and of tannin and opium, and the internal administration of anti-gouty remedies, was employed for four months without much effect, the walls of the meatus still remaining much swollen, and discharging. Drops of glycerine of borax were then ordererl on March 6th, and on March $26 \mathrm{th}$, the ears felt much better, and there was only a very little discharge in each meatus, of a thick, white character. On April r6th, there was no fluid discharge in the ears; only a few scales. The small process of the hammer was coming into view on both membranes, and the latter were resuming their normal grey colour. On May 8th, the right meatus was clear, and the left only contained a small quantity of thick, blaskish material. Both membranes were normal, with the exception of being slightly dull on the surface, and there was scarcely any swelling of the canals. The hearing also (the patient refor:ed) was as good as it ever had been. Eleven months after this date this lady was again seen, and it was found that the ears had continued quite well.

The borax drops certainly appear to have acted very satisfactorily in this case ; but it is possible that the removal of the patient from this town to London, to different surroundings, which tork place about the time that these drops were commenced, had a good effect on the disease.

I will conclude with very a brief account of an acute case, of which the course contrasts markedly with that just described.

Elizabeth II., aged 23, was admitted a patient at the Throat and Ear Dispensary on January 3 Ist, 1879 . The history was, that sixteen days before, after a very bad cold in the head, violent pain began in the left ear, which had been aching ever since. Deafness came on in the left ear at the same time; also a noise like something drumming or spinning. Her own voice sounded lourer in the left ear. She had previously never had anything the matter with the left ear. Movement of the lower jaw produced pain, rendering her unable to eat solids. The watch was only heard in the left ear, on contact with the auricle, temple, and mastoid ; and the tuning-fork applied to the median line was heard louder on the left side. There were tenderness and swelling in front of the left tragus, and the left mastoid was slightly tender on pressure, but not swollen. The walls of the meatus were much swollen. One of Gruber's morphia globules was inserted into the left ear. The patient was seen again at seven o'clock the same evening, when it was found that the pain became easier after insertion of the globule, but had grown worse again. Ten drops of a solution of morphia (one grain to one drachm) were ordered to be instilled into the ear every hour, until the pain was relieved. The following day (February Ist) she reported that she had had a better night, and the pain was easier. Much sodden epidermis was removed from the canal; but even after removal of this the drumbead was not visible. Morphia ointment was inserted on cotton-wool, and a leech ordered to the front of the tragus. On Poliz zerising, there was no perforation-sound. The mastoid process was not tender. To make a long story short, the swelling of the walls of the meatus gradually subsicied, the pain ceased, and the membrana tympani began to resume its natural appearance. On February 7 th (i.e., a week after she was first seen), the hammer was first slightly visible, and the hearing for the watch had risen to nine inches. On the I9th, the watch was heard at a distance of three feet, and a whisper could be repeated across the room, so that the hearing was practically restored. A few days after this, the patient ceased attending, the left membrana tympani still being slightly dull, and the hammer indistinct. There was evidence in this case that the tympanum was also slightly affected; and indeed it is probable that, in such an acute case, affecting the osseous meatus, the middle ear would, to a certain extent, participate in the congrestion.

In conclusion, I must ask your indulgence for the necessarily imperfect character of this sketch ; but, without unduly prolonging the paper, I was unable to enter into further details. I trust, however, that I have touched on most of the practical points connected with the subject.

THE honorary membership of the New York Medico-Legal Society has been conferred on Mr. Jabez Hogg, Consulting Surgeon to the Royal Westminster Ophthamic Hospital.

\section{EXTRACTION OF CATARACT.}

BY P. H. MULES, M.D.,

Surgeon to the Manchester Royal Eye Hospital.

In publishing these notes of all the cases operated on by me during the past two years, I trust no apology is needed. I am inclebted to Mr. A. Iill Griffith for verifying all save the first nine, which were completed before his connection with our hospital; and for his care in testing the vision, and corroborating the results.

The operation known as the "modified linear of von Gräfe", with such further modifications as the nature of the complication demanded, has been adopted in each case.

The first portion of the table refers to complicated, the remainder to uncomplicated, cases. Of the complicated cases-including cases of locomotor ataxy; diabetes (very feeble, one eye lost from spontaneous irido-choroiditis); sympathetic cataract, with matted iris (rheumatoid arthritis bedridden, and double senile cataract); besides nine others of less apparent gravity-all recovered satisfactorily. Of the uncomplicated, the sixty-ninth (aged 78) was lost by panophthalmitis ; the remainder gave satisfactory results.

Vitreous humour was lost in two of the uncomplicated cases, and in two of the complicated, making four losses of vitreous humour in seventy-seven cases, two of which were unavoidable. Secondary capsular troubles were needled in seven cases, but it is probable that distant vision of many would have improved if the films had been systematically divided. Iritis attacked six eyes, which were treated satisfactorily, the vision being respectively 1 and $6.12 ; 1$ and 6.18 ; and I and 6.I2. The wound was enlarged with scissors for the passage of the lens in six cases. This appears infinitely preferable to the introduction of traction-instruments, or excessive pressure for the extrusion of the lens. The spoon was used in four cases. Closed pupil recurred in the sympathetic case, when iridotomy gave Io J. + is D. The pupil was enlarged three times : once for arrest of glaucoma; once to obtain a pupil opposite a clear portion of cornea; once to lower the pupil in a case of ptosis.

The number of patients operated on was seventy-two. Five double extractions brings the number of operations to seventy-seven. Of these, fifty-nine read No. I Jiger (brilliant), seven read 2 to 6 Jiger (bourgeois), eight read 6 to 20 Jäger ; two count fingers; and in one vision was lost. Thus, out of seventy-seven extractions, seventy-six were surgically successful, and more or less risually so; sixty.six having good distant vision.

Cylindrical lenses were only occasionally added to the sphericals, their cost precluding their general adoption.

The comparative absence of iritis may appear to be somewhat un usual. This may be fairly attributed to the manner in which the iridectomy is performed, and to the care with which the wounded iris is freed from cortex and capsule.

The method of performing the iridectomy which I find best is not new ; but, as it is in direct opposition to the views of one of our latest writers, I am tempted to give it in extenso. The iris is grasped by forceps as near as possible to either angle of the wound, gently stretched, cut through about four-fifths of its length; the forcens, with the cut iris in its grasp, being immediately carried over to the opposite angle of the wound, the iris is again gently stretched, and the iridectony completed. By this mancuure, all fear of entangling the iris in the wound, either before or during the extrusion of the lens, may be dismissed. The colobona is perfect-small at the pupillary margin, broad at the base. Weiss's forceps-scissors are particularly handy for this operation. The objections to this mode of performing the iridectomy can only be theoretical ; as in my own practice, and others, incarcerated iris was an element of danger and trubble, of times necessitating removal of small portions from each angle of the wound; whilst, since its adoption, I have not had one case of disentangling or removal. The final clearing of the pupil from cortex, admirably described by von Gräfe, is the most difficult as well as the most important part of the operation, and is conducted by the points of the fingers after removal of the speculum.

The subsequent treatment is adapted to the requirements of each case, great care being taken not to expose the wound, or to raise the upper lid for the first few days, all examination being conducted by depressing the lower lid. The hospital happily rejoices in trustworthy and intelligent nurses, who have been long there, and to whose promptitude in relieving the earlier discomforts may be attributed the com. 
parative immunity from those secondary troubles which are occasionally so disastrous.

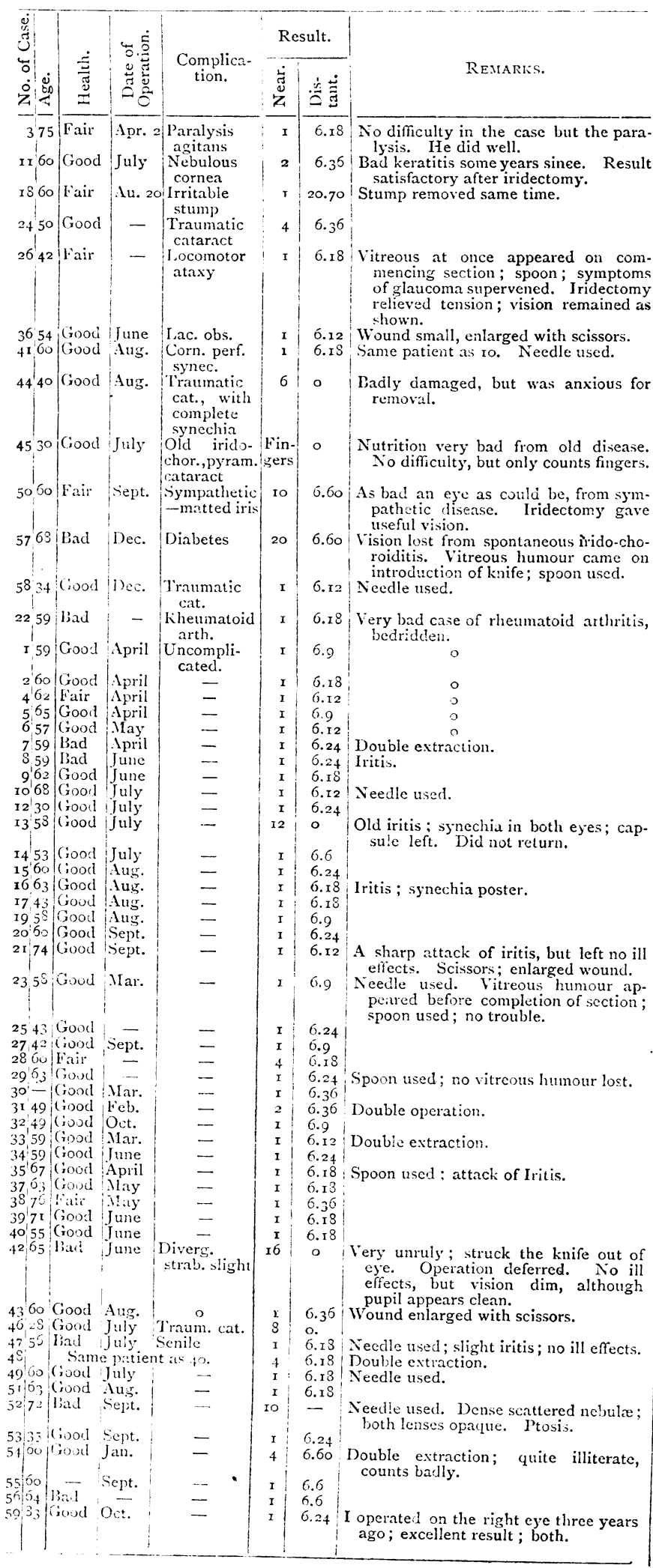

TABLE-continued.

\begin{tabular}{|c|c|c|c|c|c|c|}
\hline 苞 & & ๘ & & & esult. & \\
\hline ن & 嶂 & 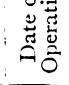 & $\begin{array}{l}\text { Complica- } \\
\text { tion. }\end{array}$ & $\begin{array}{c}\dot{3} \\
\text { 乙 }\end{array}$ & $\dot{\dot{a}} \dot{\vec{\Xi}}$ & RFMARKS. \\
\hline 6065 & Good & Nov. & - & I & 6.18 & \\
\hline 6170 & Good & Dec. & - & I & 6.18 & \\
\hline 6240 & Bad & Dec. & - & 6 & 6.60 & Capsule to be needled; will see well. \\
\hline 6371 & Good & Jan. & $-\quad-$ & I & 6.36 & Double extraction. \\
\hline 6447 & Good & Jan. & Traum. cat. & I & 6.18 & Vitreous humour lost. \\
\hline 6565 & Fair & Jan. & $\begin{array}{l}\text { Nuclear, } \\
\text { senile }\end{array}$ & I & 6.24 & \\
\hline $66 \cdot 63$ & Good & Feb. & - & I & 6.9 & $\begin{array}{l}\text { Bad chronic bronchitis. Kept in hos- } \\
\text { pital, with firm bandage, one month. }\end{array}$ \\
\hline $\begin{array}{l}6760 \\
6868\end{array}$ & $\begin{array}{l}\text { Fair } \\
\text { Fair }\end{array}$ & $\begin{array}{l}\text { Feb. } \\
\text { Feb. }\end{array}$ & 二 & I & $\begin{array}{l}6.12 \\
6.18\end{array}$ & \\
\hline 6978 & $\mathrm{Bad}$ & Mar. & - & $\circ$ & $\circ$ & $\begin{array}{l}\text { Very feeble old woman. Opcration } \\
\text { very easy and satisfactory. Panoph- } \\
\text { thalmitis. Vision lost. }\end{array}$ \\
\hline $\begin{array}{lll}70 & 68 \\
7 \times & 08\end{array}$ & $\begin{array}{l}\text { Good } \\
\text { Good }\end{array}$ & $\begin{array}{l}\text { Mar. } \\
\text { April }\end{array}$ & $1=$ & $\begin{array}{l}4 \\
\mathrm{x}\end{array}$ & $\begin{array}{l}6.18 \\
6.18\end{array}$ & Slight iritis. \\
\hline 7233 & Good & April & Doubtful & Fin- & 一 & $\begin{array}{l}\text { Small separation of retina, extending } \\
\text { to almost complete. }\end{array}$ \\
\hline $\begin{array}{l}7375 \\
7464\end{array}$ & $\begin{array}{l}\text { Good } \\
\text { Good }\end{array}$ & $\begin{array}{l}\text { April } \\
\text { April }\end{array}$ & $\begin{array}{l}\text { Senile } \\
\text { Senile }\end{array}$ & $\mid \begin{array}{l}\mathrm{S} \\
\mathrm{I} \\
\mathrm{I}\end{array}$ & $\begin{array}{l}6.9 \\
6.12\end{array}$ & Scissors; enlarged wound. \\
\hline 7568 & Good & April & - & I & 6.18 & Capsule to be cut. \\
\hline \begin{tabular}{l|l}
76 & 64 \\
77 & 75
\end{tabular} & Good & April & - & I & 6.12 & \\
\hline 7775 & Good & & & I & & \\
\hline
\end{tabular}

\section{THE USE OF ALCOHOL IN RELATION TO PUBLIC HEALTH.}

BY LEWIS SHAPTER, M.D.CANTAB.,

Physician to the Devon and Exeter Hospital, and to the West of England Institution for the Deaf and Dumb.

ONE of the vexed questions of the day, bearing prominently upon the preservation of public health, is undoubtedly the popular use, and consequent abuse, of alcoholic stimulants. That the wide spread abuse of alcohol has developed into a national danger, is a proposition scarcely open to question : but it must at the same time be admitted that we have not yet arrived at a remedial measure of prevention and cure for this abuse which can be rendered generally acceptable, either from a scientific or a logical point of view. Medical men have, for example, very generally held aloof from entering upon the controversy upon which the admission of this abuse inevitably leads them, because, in all probability, as the cautious and logical advisers for the public welfare, they have not seen their way to propound total abstinence or any doctrine of totalism as a remedial measure for want of moderation or intemperance ; and because, moreover, to adopt total abstinence from alcohol, is to throw over a remedial agent which may be not only curative but preventive of disease. Whereas, therefore, on the one hand, medical men should not shrink from grappling with a national evil prejudicial to health, and boldly offering measures remedial and preventive, yet, upon the other hand, it becomes them to act with such extreme circumspection as shall render their views clear and reasonable for the present as well as fruitful for the future.

The question which underlies the whole matter of the popular use of alcohol appears to be this : Is there a general necessity for the use of some restorative beverage; and, if so, does alcohol fulfil the requirement with safety and efficiency? If it do not, and the necessity remain, we must clearly look for a substitute; but if it do, we have only to deal with its abuse, and not with its acceptation.

Medically speaking, the chief remedial use of alcohol is as a food, and as a present stimulant to a circulation which without its temporary aid might disastrously fail. As a food, there is probably no other substance which can effectually perform the same functions. In typhoid fever for example, a fever of protracted, but limited duration, where the vital functions tend proportionately to fail, and endanger the power of resistance until the close, alcohol may confidently be looked to as the most readily assimilated food, and the most effectual temporary stimulant.

Like other kinds of heat-giving foods, alcohol undergoes oxiclation within the body; and, in yielding up its carbon and hydrogen in the formation of carbonic acid gas and water, it incluces the development of heat, and proportionately diminishes tissue waste and checks the necessity for other kinds of food. The other action of alcohol is that it excites the vascular system and stimulates for present purposes a failing circulation, so as to carry it through the limited duration of the attack, but, like all indirect excitants to the nervous system, it subsequently depresses. The necessity for the stimulating action of alcohol to the vascular system arises more especially towards the close of a prolonged acute illness like typhoid fever; but prior to this period, so long as the assimilative and 